\title{
First report of canker and dieback caused by Cytospora viticola on grapevine in Turkey
}

\author{
Erçin Oksal ${ }^{1}$ (1) $\cdot$ Yusuf Çelik ${ }^{2} \cdot$ Göksel Özer $^{3}$
}

Received: 5 April 2019 / Accepted: 23 July 2019 /Published online: 31 July 2019

(C) Società Italiana di Patologia Vegetale (S.I.Pa.V.) 2019

Keywords Grapevine trunk disease · Cytospora canker · Vitis · Turkey

Cytospora species are seriously damaging pathogens causing canker and dieback on several woody hosts of agronomic, forestry, and ornamental importance. In June 2018, symptoms of trunk diseases on plants including death of branches, diagnostic chlorotic foliage with necrotic margins, and brownish discoloration inside the wood were observed with an incidence of up to $10 \%$ in grapevine (Vitis vinifera L.) fields in the Arapgir district of Malatya. To obtain fungal isolates, necrotic woody tissues were surface disinfected with $1 \%$ sodium hypochlorite for $60 \mathrm{~s}$ and twice rinsed, air dried, and placed onto $2 \%$ malt extract agar (MEA) (Merck, Darmstadt, Germany) amended with tetracycline $(0.01 \%)$. Petri dishes were incubated at $25{ }^{\circ} \mathrm{C}$ in the dark for three weeks. A total of 14 isolates were obtained and identified as Cytospora viticola D.P. Lawr., Travadon \& Pouzoulet based on morphological characteristics of white to light straw-coloured colony, dark-brown pycnidia measured $947-1618 \mu \mathrm{m}$ in diameter $(n=20)$ and pycnidiospores were hyaline, allantoid, aseptate, and ranged from 4.2 to $6.1 \mu \mathrm{m}$ in length $\times 1.1$ to $1.8 \mu \mathrm{m}$ in width $(n=50)$ on MEA (Lawrence et al. 2017). No teleomorphic stage was observed. DNA sequences of Internal Transcribed Spacer (ITS) region, part of the $\beta$-tubulin gene (BT2), and part of

Erçin Oksal

oksalercin@gmail.com

1 Department of Plant Protection, Faculty of Agriculture, Malatya Turgut Ozal University, 44210 Malatya, Turkey

2 Arapgir District Directorate of Agriculture and Forestry, Republic of Turkey Ministry of Agriculture and Forestry, 44800 Malatya, Turkey

3 Department of Plant Protection, Faculty of Agriculture and Natural Sciences, Bolu Abant Izzet Baysal University, 14020 Bolu, Turkey the translation elongation factor $1-\alpha$ gene $(E F 1-\alpha)$ from a reference grapevine isolate of C. viticola (Arp2-D) were amplified, sequenced, and deposited in the GenBank database (MK706295, MK715441, and MK715442, respectively). Resultant sequences showed 99-100\% identity with those of C. viticola isolate Cyt21 (ITS: KX256244, BT2: KX256223, EF1- $\alpha$ : KX256265). Pathogenicity assays were conducted using disinfected 2-year-old twigs of $V$. vinifera $\mathrm{cv}$. Köhnü plants inoculated by placing 5-mmdiameter mycelial plugs excised from ten-day colonies into wounds made by removing the bark with a cork borer, while the control plants were inoculated with sterile agar plugs. Inoculated plants were then incubated at $25{ }^{\circ} \mathrm{C}$ in a 12-h photoperiod. After 21 days, symptoms of inner bark discoloration were observed in vascular and cortex tissues from which the pathogen was reisolated successfully to fulfill Koch's postulates. No symptoms were observed in the control plants. To our knowledge, this is the first report of canker and dieback caused by $C$. viticola on grapevine in Turkey; the pathogen has been currently reported in the USA and Canada (Lawrence et al. 2017; Farr and Rossman 2019).

\section{References}

Farr DF, Rossman AY (2019) Fungal Databases, U.S. National Fungus Collections, ARS, USDA. https:/nt.ars-grin.gov/fungaldatabases/. Accessed 6 May 2019

Lawrence DP, Travadon R, Pouzoulet J, Rolshausen PE, Wilcox WF, Baumgartner K (2017) Characterization of Cytospora isolates from wood cankers of declining grapevine in North America, with the descriptions of two new Cytospora species. Plant Pathol 66:713725. https://doi.org/10.1111/ppa.12621

Publisher's note Springer Nature remains neutral with regard to jurisdictional claims in published maps and institutional affiliations. 